\title{
Upaya Peningkatan Kualitas Pembelajaran Daring bagi Peserta Didik MI/SD pada Masa Pandemi Covid-19
}

\author{
UhlulQoriawati, Lu’luil Maknun \\ UIN SyarifHidayatullah Jakarta \\ *E-mail: Uhlulq@mail.com, maknun@uinjkt.ac.id
}

\begin{abstract}
Abstrak
Penelitian memiliki tujuan untuk mengetahui bagaimana cara meningkatkan kualitas pembelajaran daring bagi peserta didik MI/SD pada masa pandemic Covid-19. Metode yang dipakai dalam penelitian ini menggunakan metode kualitatif yang bersifat studi pustaka dengan teknik mengumpulkan informasi data yang relevan melalui dokumen, buku, majalah, berita. Penelitian menggunakan metode kualitatif dengan menghasilkan informasi berupa catatan dan data deskriptif yang terdapat dalam dokumen yang diteliti. Dalam memutus penyebaran virus Covid-19 pemerintah menekankan untuk kegiatan pembelajaran dilaksanakan di rumah masing-masing dengan menggunakan pembelajaran daring. Pada penelitian ini telah mendapatkan informasi bahwa masih banyak factor-faktor yang menjadi penghambat pendidik, para siswa MI/SD, dan juga orang tua dalam penerapan pembelajaran daring. Dengan pelaksanaan pemebelajaran daring yang dilakukan di rumah menimbulkan masalah bagi peserta didik dan juga pendidik seperti penyampaian pembelajaran yang tidak terpenuhi untuk disampaikan akhirnya peserta didik diberikan tugas tambahan, akibatnya tugas yang dimiliki peserta didik menjadi bertambah banyak, hal terebut dapat menjadi beban bagi peserta didik, pendidik dan juga orang tua. Pelaksanaan pembelajaran daring harus segera diperbaiki untuk meningkatkan kualitas pendidikan pada masa pandemic Covid-19.
\end{abstract}

Kata kunci: Covid 19, pembelajaran daring, penghambat pembelajaran

\section{PENDAHULUAN}

Dunia sedang dihadapkan dengan masalah munculnya wabah coronavirus termasuk negara Indonesia juga terpapar dari virus tersebut. Coronavirus atau Covid19 merupakan bagian dari virus yang dapat menginfeksi saluran pernapasan. Gejala umum bagi orang yang terkena virus Covid-19 biasanya akan mengalami batuk, demam, dan sesaknapas. Munculnya wabah virus Covid-19 berdampak di berbagai bidang seperti sosial, ekonomi, pariwisata dan juga pendidikan. Virus Covid-19 juga berdampak bagi pendidikan sehingga Menteri Pendidikan dan Kebuyaan Republik Indonesia pada tanggal 24 Maret 2020 mengeluarkan surat edaran yang berisi proses belajar dilaksanakan di rumah masing-masing melalui pembelajaran jarak jauh/daring (Wahyu, 2020).

Proses pembelajaran daring dilakukan agar kegiatan pendidikan di negara Indonesia bisa terus berjalan dengan efektif dan dapat meningkatkan kualitas pendidikan pada masa pandemi Covid-19, terutama untuk peserta didik MI/SD akan terus mendapatkan materi pelajaran dari gurunya sehingga para peserta didik tidak 
tertinggal dalam proses pendidikannya. Pembelajaran daring ini juga merupakan sebuah inovasi dalam pendidikan sebagai salah satu sumber belajar yang variatif. Tingkat keberhasilan berdasarkan model dan media pembelajaran tergantung pada karakteristik yang dimiliki peserta didik. Menurut (Nakayama, 2007) menjelaskan di dalam literature e-learning bahwa, tidak seluruh peserta didik akan berhasil dalam kegiatan belajar mengajar yang dilakukan secara online, tingkat keberhasilan peserta didik dalam pembelajaran online bergantung pada faktor lingkungan dan karakteristik peserta didik itu sendiri.

Sebagai salah satu usaha untuk menghindari penularan virus Covid-19 di negara Indonesia, maka sistem pembelajaran dilakukan secara daring. Pembelajaran daring merupakan sebuah pembelajaran yang dilaksanakan dalam jarak jauh dengan menggunakan media berupa internet dan alat penunjang seperti Handphone, computer, laptop. Melalui pembelajaran daring peserta didik MI/SD akan terbiasa terlatih untuk teliti dalam menerima dan mengolah informasi yang disajikan melalui online (Hilna dkk, 2020). Sebelumnya dalam pelaksanaan pembelajaran daring yang pernah dilakukan mengharuskan pendidik untuk merespon dengan sikap dan tindakan ingin belajar mengenai hal-hal yang baru. Penyusunan materi dan penggunaan alat media pembelajaran yang digunakan pada proses pembelajaran daring yangdilakukan oleh pendidik dan peserta didik harus disesuaikan dengan tingkat perkembangan intelektual peserta didik, hal ini dilakukan agar peserta didik lebih mudah memahami materi-materi yang diberikan (Wiryanto, 2020).

Pada kenyataannya selama pembelajaran daring berlangsung banyak orang tua dari peserta didik mengeluh karena ada beberapa masalah yang dihadapinya selama peserta didik belajar di rumah, keluhan tersebut antara lain seperti banyaknya tugas yang diberikan oleh guru, dan fasilitas internet yang kurang memadai sehingga pembelajaran mengalami sedikit keterlambatan. Selain itu, pada penerapan pembelajaran daring juga terdapat kelebihan antara lain adanya keluwesan waktu dan tempat belajar yaitu peserta didik dapat belajar di mana saja yang penting masih tetap berada di dalam rumah misalnya belajar di ruang tamu, halaman rumah dan peserta didik juga tidak harus pergi ke sekolah terlebih dahulu untuk belajar. Dengan pembelajaran daring juga dapat membangun suasana baru bagi peserta didik sehingga dapat menumbuhkan sikap antusias peserta didik dalam belajar (Mirzon dkk, 2020).

Berdasarkan permasalahan yang telah diuraikan, maka tujuan dari penulisan artikel untuk memberikan gambaran tentang bagaimana cara meningkatkan pembelajaran daring bagi peserta didik MI/SD pada masa pandemik Covid-19 agar kegiatan proses pembelajaran dapat terus berjalan dengan baik, serta untuk menganalisis keefektifan penerapan pembelajaran bagi peserta didik MI/SD. Dengan menerapkan proses pembelajaran daring sebaiknya seorang guru lebih paham mengenai media yang dipakai untuk kegiatan pembelajaran, metode pembelajaran dan 
materi belajar dapat disajikan secara menarik dan jelas agar peserta didik lebih mudah memahami serta tidak cepat merasa bosan, dalam pelaksanaannya orang tua juga berperan untuk membantu peserta didik melaksanakan pembelajaran daring di rumah (Briliannur, 2020).

Berdasarkan latar belakang di atas, peneliti merasa perlu untuk melakukan penetlitian dengan judul "Meningkatkan Pembelajaran Daring bagi Peserta Didik MI/SD pada Masa Pandemi Covid-19".

\section{METODE/EKSPERIMEN}

Penelitian ini menggunakan metode penelitian atau pendekatan kualitataif yang bersifat studi pustaka. Penelitian kualitatif merupakan sebuah metode penelitian yang dapat menghasilkan data deskriptif berupa kata-kata tertulis atau lisan dari narasumber serta perilaku yang diamati. Pada artikel ini menggunakan pendekatan kualitatif yang bersifat studi pustaka yaitu serangakaian kegiatan yang berkenaan dengan metode pengumpulan data pustaka dengan cara membaca dan mencatat serta mengolah bahan penelitian. Dalam penelitian studi pustaka penulis atau peneliti harus berhadapan langsung dengan teks atau data angka, dan tidak harus turun langsung ke lapangan untuk memperoleh pengetahuan. Pengumpulan data dalam penelitian dilakukan dengan memahami dan mengeksplorisasi beberapa jurnal, buku, dan sumber-sumber data atau informasi yang dianggap relevan dengan penelitian (Antar \& Supriyadi, 2016). Untuk mendapatkan data yang lebih spesifik peneliti dapat menganalisis tulisannya dengan cara membandingkan karya tulisnya dengan karya tulis miliki orang lain. Studi pustka ialah teknik pengambilan data yang mempunyai tujuan untuk memecahkan suatu masalah. Dalam proses pembuatan artikel ini, penulis mengumpulkan seluruh data yang berkaitan dengan tema bahasan yaitu "Meningkatkan Pembelajaran Daring bagi Peserta Didik MI/SD pada Masa Pandemi Covid-19". Kemudian, setelah penulis mengumpulkan sumber-sumber yang relevan lalu penulis memabaca secara mendalam, menganalisis data dan meringkas kembali menjadi sebuah kesimpulan.

\section{HASIL DAN PEMBAHASAN}

\section{Hasil}

Kualitas pendidikan pada saat pandemi Covid-19 harus tetap ditingkatkan agar kebutuhan peserta didik dalam menerima ilmu pengetahuan dapat terpenuhi. Maka dari itu, pemerintah telah menetapkan metode pembelajaran daring sebagai solusi agar proses belajar mengajar masih tetap berjalan saat negara Indonesia mengalami pandemi Covid-19. Kendala serta hambatan dari pembelajaran daring juga harus segera mendapatkan solusi agar kegiatan belajar mengajar dapat berjalan dengan kondusif.

Dalam metode daring peserta didik diharuskan berhadapan dengan teknologi untuk mendukung kegiatan proses pendidikan. Agar proses pembelajaran dapat 
berjalan dengan efektif maka sekolah juga harus menyiapkan alat dan bahan untuk digunakan sebagai bahan ajar dalam metode daring yang dilakukan dengan jarak jauh. Agar peserta didik dapat menjadi pembelajar online yang aktif maka peserta didik harus dihadapkan pada berbagai pengalaman belajar (Zapalska, 2006).

Kegiatan pendidikan dalam proses pengajaran juga akan lebih kondusif jika dalam penyajian materi didukung dengan media pembelajaran. Penyediaan media serta metodelogi pendidikan yang dinamis, kondusif sangat diperlukan dalam mengembangkan potensi peserta didik secara optimal. Factor tersebut dikarenakan potensi peserta didik akan lebih terangsang jika dalam penyampaian materi dibantu dengan media, fasilitas yang mendukung dalam menjalankan kegiatan pembelajaran. Pemilihan metode pembelajaran juga dapat menggunakan media animasi, gambar maupun video yang akan menjadikan peserta didik MI/SD aktif dalam kegiatan pembelajaran (Nur, 2020) .

Komunikasi antara guru dengan peserta didik MI/SD harus tetap terjaga dengan baik agar materi yang diampaikan ke peserta didik dapat dipahami dengan baik, maka dari itu dalam penerapan pembelajaran daring seorang guru harus mampu merubah gaya komunikasinya, yang biasanya hanya berkomunikasi satu arah dan biasanya menciptakan kegiatan diskusi dengan peserta didik pada masa pendemi Covid 19 membuat peserta didik menjadi kurang aktif dan kurang termotivasi untuk melakukan kegiatan diskusi secara online, maka dari itu seorang guru harus selalu siap untuk membangun semangat yang ada di dalam diri peserta didik melalui komunikasi yang baik. Bagi para guru yang kurang mahir terhadap penggunaan teknologi maka sebaiknya guru tersebut mengikuti pelatihan dan perlu dampingan dalam menggunakan teknologi untuk mengajar.

Agar kegiatan pembelajaran daring bagi peserta didik MI/SD dapat berjalan dengan efektif maka setiap instansi yang terkait dalam kegiatan pembelajaran daring harus mempersiapkan fasilitas pendukung seperti memberikan pelatihan kepada guru, peserta didik, dan juga orang tua. Dalam pelaksanaan pembelajaran daring juga diperlukan dukungan dan kerja sama orang tua, begitu pula komunikasi antara guru dan orang tua juga harus tetap terjalin. Kemudian, setiap peserta didik juga harus memiliki fasilitas yang memadai seperti laptop, handhpone serta kuota internet. Maka dari itu orang tua dirasa perlu untuk mempersiapkan fasilitas pembelajaran untuk anaknya (Agus dkk, 2020).

\section{Pembahasan}

Saat wabah Covid-19 melanda negara Indonesia, maka pemerintah mengeluarkan beberapa peraturan sebagai upaya memutus mata rantai penyebaran Covid-19 diantaranya yaitu himbauan untuk melakukan social distancing bagi setiap individu. Social distancing yaitu menjaga jarak, misalnya seperti menghindari kerumunan dan melakukan kontak fisik. Peraturan social distancing ini tentu berdampak pada bidang pendidikan. Pembelajaran yang awalnya dilakukan di sekolah 
sebagai tempat untuk menumbuhkan potensi sosial pada peserta didik, serta melakukan interaksi secara langsung dengan guru dan teman-teman yang lainnya (Baharain, 2020), diubah menjadi pembelajaran yang dilakukan di rumah masingmasing (Oktafia, 2020).

Pada masa pandemi Covid-19 proses pendidikan harus tetap berjalan agar dapat mencapai tujuan pendidikan yang dicita-citakan. Dalam melaksanakan kegiatan pembelajaran selama masa Covid-19, seoarang guru harus tetap melaksanakan tugasnya secara baik yaitu sebagai fasilitator dalam kegiatan pembelajaran. Kegiatan pembelajaran selama pandemi Covid-19 dilaksanakan secara Daring. Pembelajaran daring merupakan salah satu usaha yang dilaksanakan dalam mengatasi masalah pendidikan tentang penyelenggaraan pembelajaran. Metode belajar daering merupakan sebuah metode belajar dengan memanfaatkan model interaktif dengan bantuan internet dan Learning Manajemen System (LMS) seperti menggunakan aplikasi Zoom, Google Meet, Google Drive, dan aplikasi lainnya yang dapat digunakan sebagai alat pembelajaran (Hasibuan dkk, 2019).

Menurut (Michael,2013) menjelaskan mengenai pembelajaran daring merupakan suatu tujuan dengan memanfaatkan system eltronik untuk mendukung berjalannya proses pembelajaran. Sedangkan, menurut (Chandrawati, 2010) menjelaskan mengenai pengertian dari pembelajaran e-learning/daring merupakan gabungan dari prinsip-prinsip untuk melakukan kegiatan pembelajaran yang menggunakan teknologi. Manfaat dari pembelajaran e-learning/daring ini antara lain fleksibelitas karena dapat menentukam waktu dan tempat yang diinginka, pembelajaran daring juga dapat membiasakan peserta didik untuk belajar mandiri (Setiawan, 2020).

Penerapan pembelajaran daring menimbulkan dampak dan kendala yang dirasakan oleh peserta didik, guru dan juga orang tua. Dampak yang dialami oleh peserta didik antara lain pembelajaran daring dapat menyebabkan peserta didik kurang memahami materi pelajaran yang telah disampaikan oleh gurunya. Pembelajaran daring juga akan terasa membosankan apabila terlalu banyak tugas yang diberikan kepada peserta didik, maka dari itu sebagai pendidik harus selalu berinovasi dalam menggunakan metode pembelajaran. Fokus pembelajaran dapat mengaitkan materi pelajaran dengan kehidupan nyata peserta didik sehingga peserta didik dapat menghubungan situasi nyata dengan pengetahuan yang dimilikinya. Dengan begitu, peserta didik akan termotivasi untuk memperoleh pengetahuan sebanyak-banyaknya karena rasa ingin tau yang tinggi (Syaharuddin \& Mutiani, 2020).

Fasilitas yang kurang memadai juga akan menjadi hambatan untuk peserta didik dalam melaksanakan pembelajaran daring, akibatnya peserta didik kurang memiliki motivasi dalam mengikuti pembelajaran daring. Peserta didik akan dihadapkan dengan system online yang pembelajarannya hanya akan berupa teori saja. Berbeda dengan biasanya, peserta didik dapat melakukan praktik, karena adanya 
pandemic Covid-19 membuat penyampaian materi hanya dengan teori hal ini akan menyebabkan peserta didik mengalami keterlambatan dalam memahami pembelajaran, apalagi bila dilihat dari daya serap yang dimiliki peserta didik berbedabeda, yaitu ada peserta didik MI/SD yang cepat memahami pembelajaran secara baik dan ada juga peserta didik MI/SD yang lambat dalam memahami materi.

Guru juga mengalami kendala dalm proses pembelajaran di era pandemic Covid-19 diantaranya guru yang awalnya terbiasa melakukan pembelajaran secara konvensional berubah menjadi pembelajaran secara online. Guru harus tetap menyiapkan metode pembelajaran agar kegiatan pembelajaran tetap dapat berjalan dengan kondusif dan efisien. Dengan begitu, sebaiknya pendidik harus menyesuaikan metode, gaya, dan strategi pembelajaran dengan pembelajaran online. Metode yang dipakai sebaiknya dapat memaksimalkan proses belajar mengajar agar materi pelajaran dapat dipahami dengan baik oleh para peserta didik MI/SD (Mastura, 2020).

Pembelajaran daring yang harus menggunakan internet juga menjadi masalah ekonomi yang dialami para orang tua dari peserta didik. Orang tua harus menyiapkan fasilitias seperti handphone, computer, laptop dan juga memerlukan kuota agar dapat terhubung dengan internet. Hal tersebut membuat beban ekonomi orang tua menjadi bertambah, dalam pemebelajaran daring orang tua juga harus lebih banyak meluangkan waktu untuk mendampingin anak-anaknya karena pembelajaran daring ini pengalaman pertama bagi peserta didik sehingga peserta didik masih memerlukan pengawalan dan pengarahan dari orang tua peserta didik. Begitu pula dengan guru yang tidak bisa dan belum mahir dalam penggunaan teknologi akan menjadi penghambat dalam proses mengajar akibatnya peserta didik menjadi terlambat dalam menerima materi pelajaran. Dengan begitu, sebelum melaksanakan pembelajaran daring seorang guru harus lebih memahami terlebih dahulu mengenai teknologi yang akan dipakai dalam pembelajaran sehingga tidak akan terjadi kendala selama pembelajaran daring berlangsung . (M Hadi, 2020)

Penerapan pembelajaran daring bisa berdampak positif dan berdampak negatif. Dampak positif dari penerapan pembelajaran daring pada peserta didik MI/SD antaralain peserta didik akan belajar mengenal penggunaan teknologi, peserta didik dapat melakukan pembelajaran kapanpun dan dimanapun tanpa harus pergi ke sekolah, dapat meningkatkan kualitas serta efektivitas, peserta didik mendapatkan pengalaman baru untuk dirinya. Sedangkan dampak negatif dari penerapan pembelajaran daring bagi peserta didik MI/SD antara lain pemahaman materi yang didapat peserta didik kurang mendalam, penilaian hanya dilakukan melalui penilaian hasil saja, kebutuhan kuota internet meningkat sehingga beban bayaran yang dikeluarkan juga bertambah.

Agar pembelajaran daring dapat berjalan dengan efektif, sebaiknya guru mempersiapkan terlebih dahulu mengenai materi-materi yang akan disajikan kepada peserta didik MI/SD dapat dikemas dengan menarik agar peserta didik tidak mudah 
bosan dan pembelajaran jadi menyenangkan dengan begitu peserta didik MI/SD akan cepat mengerti. Orang tua juga harus berperan untuk berpatisipasi aktif dalam membangun motivasi belajar anaknya dan mendampingi anaknya selama pembelajaran dilaksanakan. Sikap disiplin juga harus diterapkan pada peserta didik agar dapat menggunakan waktu sebaik-baiknya untuk mendalami materi-materi yang telah disiapkan oleh guru (Wiryanto, 2020).

\section{PENUTUP}

Berdasarkan hasil penelitian maka diketahui pandemi Covid-19 sangat memberi dampak pada dunia pendidikan. System pembelajaran yang biasanya dilaksanakan di sekolah dengan tatap muka secara langsung kini berubah menjadi system pembelajaran daring. Penerapan pembelajaran daring pada masa pandemi Covid-19 masih dianggap kurang efektif karena masih banyak hambatan yang dialami oleh peserta didik, guru dan juga orang tua.

Segala hambatan yang disebabkan karena penerapan pembelajaran daring dapat di minimalisin dengan mengadakan pelatihan kepada guru, peserta didik, dan orang tua sebelum melaksanakan pembelajaran daring, kemudia orang tua mempersiapkan fasilitas yang dibutuhkan peserta didik dalam pembelajaran, strategi belajar yang diberikan peserta didik harus lebih bervariasi. Dalam pembelajaran daring orang tua juga berperan penting karean orang tua yang mengawasi serta membimbing peserta didik dalam melakukan proses pembelajara. Memberikan motivasi kepada peserta didik juga harus dilakukan agar peserta didik tetap semangat belajar walaupun hanya belajar dari rumah.

\section{UCAPAN TERIMAKASIH}

Alhamdulillah puji syukur kepada Allad swt, karena berkat kehendak dan RidhaNya peneliti dapat menyelesaikan artikel ini dengan judul Meningkatkan Kualitas Pembelajaran Daring bagi Peserta Didik MI/SD pada Masa Pandemi Covid 19. Peneliti menyadari bahwa penelitian artikel ini tidak dapat selesai tanpa doa, dukungan dan juga dorongan dari berbagai pihak. Dalam kesempatan ini peneliti ingin mengucapkan terimakasih kepada:

1. Ibu Lu'luil Maknun M.Pd selaku Dosen Mata KuliahKomposisi Bahasa Indonesia yang telah memberikan bimbingan dan arahan dalam penyusunan artikel ini.

2. Bapak Agus Setiawan dan Ibu Umi Marfuah selaku orang tua dari peneliti yang selalu mendoakandan memberikan semangat dalam menjalani penyusunan artikel ini.

\section{DAFTAR PUSTAKA}

Agus Purwanto, Rudy Pramono, Masduki Asbari, Priyono Budi Santoso, Laksmil Masyeti, Wijayanti, Choi Chi Hyun, Ratna Setyowati.2020."Studi Eksploratif Dampak Pandemi Covid-19 terhadap Proses Pembelajaran Online di Sekolah Dasar'. Journal of Education, Psychology and Counseling Vol.2 No.1

Ali Sadikin.2020."Pembelajaran Daring di Tengah Wabah Covid-19".Jurnal IImiah Pendidikan Biologi Vol.6 No.2

Andasia Malyana.2020."Pelaksanaan Pembelajaran Daring dan Luring dengan Metode 
Bimbingan Berkelanjutan pada Guru Sekolah Dasar di Teluk Betung Utara Bandar Lampung".Peadgogia:Jurnal ilmiah Pendidikan Dasar Indonesia Vol.2 No.1

Antar P \& Supriyadi P.2016." Community Of Practitioners: Solusi Alternatif Berbagi Pengetahuan antar Pustakawan".Lentera Pustaka 2(2)

Briliannur Dwi C, Aisyah Amelia, Uswatun Hasanah, Abdy Mahesha Putra, Hidayatur Rahman.2020."Analisis Keefektifan Pembelajaran Online di Masa Pandemi Covid-19". Hasibuan, MS \& Simarmata, Janner \& Sudirman, Acai.2019."E-Learning: Implementasi, Strategi dan Inovasinya".Medan.Yayasan Kita menulis

Hilna Putria, Luthfia Hamdani Maula, Din Azwar Uswatun.2020."Analisis Proses Pembelajaran Daring dalam Jaringan (DARING) Masa Pandemi Covid-19 pada Guru Sekolah Dasar".Jurnal Basicedu Vol.4 No.4

Irwan, Rustan Santaria.2020."Challenges Faced by Teacher and Students Towards Quality Assurance of Education amidst Covid 19 Pandemic".Jurnal Studi Guru dan Pembelajaran Vol.2 No.2

M Hadi Nur.2020."Pembelajaran Daring di Era Pandemi Covid 19".

Mirzon Daheri, Julian, Deriwanto, Ahmad Dibul Amda.2020."Efektifitas Wahtsapp sebagai Media Belajar daring". Jurnal Basicedu Vol.4 No.4

Nabila Nurbaiti Zulaini, Nuril Mufidah, Nur Kholis, Muhammad Afif Amrulloh.2020."Learning Arabic for Elemantary Schools During the Covid 19 Outbreak".Journal of Education Vol.3 No.1

Nakayama M, Yamamoto H.2007." The Impact of Learner Characterics on Learning Perfomance in Hybrid Courses among Japanese Students".Elektronic Journal ELearning Vol.5(3).1

Nur HAyati.2020."Metode Pembelajaran Darin/E-Learning yang Efektif'.

Oktafia Ika Handarini \& Siti Sri Wulandari.2020." Pembelajaran Daring Sebagai Upaya Study From Home (SFH) Selama Pandemi Covid-19'.Jurnal Pendidikan Adminsitrasi Perkantoran (JPAP) Vol 8 No 3

Setiawan, P.2020."Pengertian E-Learning menurut Para Ahli Karakteristik E-learning Manfaat E-Learning".

Syaharuddin S \& Mutiani M.2020."Strategi Pembelajaran IPS: Konsep dan Aplikasi". Wahyu Aji Fatma Dewi.2020." Dampak Covid-19 terhadap Implementasi Pembelajaran Daring di Sekolah Dasar".Jurnal IImu Pendidikan Vol.2 No.1

Wiryanto.2020."Proses Pembelajaran Matematika di Sekolah Dasar di Tengah Pandemi Covid-19'. Jurnal Kajian Pendidikan dan Hasil Penelitian Vol.6 No.2 Persel, C. H.1979." Educations and Inequality, The Roots and Results of Strattification in America's Schools". United States of America: The Free Press

Baharin, R.H.2020."Impact of Human Resource Investment on Labor Productivity in Indonesia".Iranian Journal of Manegement Studies, 13(1), 139-164 